IRSH 6I (20I6), pp. I I-34 doi:I0.10I 7/So0208 590 I 6000043

(C) 2016 Internationaal Instituut voor Sociale Geschiedenis

\title{
From Structuralism to Culturalism: The Protracted German Reception of The Making of the English Working Class and its Actuality Reassessed from a Post-Cold War Perspective*
}

\author{
THOMAS LIN DENBERGER \\ Zentrum für Zeithistorische Forschung \\ Am Neuen Markt I, I4467 Potsdam, Germany \\ E-mail: lindenberger@zzf-potsdam.de
}

AвSTRACT: Based on the author's experience as one of the German translators of The Making, this article lays out its protracted and contradictory reception in Germany. When E.P. Thompson's magnum opus was published fifty years ago, German scholars on both sides of the Iron Curtain failed to take note of it for several years. The relatively muted reception in West Germany during the I970s was marked by its dismissal as theory-lacking and "subjectivist". Examining the contrasting contexts of postwar Britain, with its popular anti-fascist experience, and post-fascist West Germany helps to understand why Thompson's “empirical idiom” of class history failed to strike a chord at the time with leading representatives of the new generation of "progressive" social historians in Germany and a broader reading public. It was only with the arrival of Alltagsgeschichte, feminist history, and, more generally, the cultural turn in humanities that The Making and its German translation became a canonical point of reference both in working-class history and the wider humanities. A brief epilogue discusses its lasting potential for a historical understanding of today's processes of post-Cold War class formation and human rights struggles.

Within the international community of social and (meanwhile "cultural") historians of a certain generation the encounter with Edward P. Thompson's magnum opus, The Making of the English Working Class, is often remembered as an outright revelation: "[...] and then, during my undergraduate

\footnotetext{
* The second and third sections of this article are based on an earlier German publication: Thomas Lindenberger, "Empirisches Idiom und deutsches Unverständnis. Anmerkungen zur westdeutschen Rezeption von E.P. Thompsons 'The Making of the English Working Class'”, in Stefan K. Berger, Peter Lambert, and Peter Schumann (eds), Historikerdialoge: Geschichte, Mythos und Gedächtnis im deutsch-britischen kulturellen Austausch 1750-2000 (Göttingen, 2003), pp. 439-456, 442-447, and 454-456. I am grateful to Eva Schissler for translating these passages, to Sophie Schmäing for bibliographical research, and to the three anonymous IRSH reviewers for their critical remarks.
} 
classes, I read The Making”, is a phrase I was often told by British and American scholars trying to explain to me what had inspired them during the I960s and early I 970 s when they had to pick their $\mathrm{PhD}$ subjects subjects that would lead them far from Thompson's eighteen- and nineteenthcentury England to, for instance, fields such as Stalinist Russia or Weimar Germany.

Among German history students of the same age cohort, reminiscences of such a revelatory experience are rare. Here, The Making and Thompson's oeuvre in general was discovered primarily by a small group among a new generation of social historians establishing themselves in the profession by promoting a thorough methodological innovation within social history. The group of young research fellows based at the Max Planck Institute for History in Göttingen (Alf Lüdtke, Hans Medick), to whom I am still indebted for having drawn my attention to Thompson's "Moral Economy" essay during my own undergraduate years around I 980 , was undoubtedly the most influential among these early "importers" of Thompson into the German-speaking community. ${ }^{\mathrm{I}}$

One - and the most obvious - explanation for this difference was the language obstacle: over 800 pages in English and by an author often praised for the imaginative richness of his prose was, at least then, a challenge in its own right for inexperienced readers. In addition, while reading Marxist literature - whether on one's own or as part of the syllabus - had become fashionable in West German universities during the I960s in a lot of humanities, this was certainly not the case in history. The West German undergraduate canon of Marxism gravitated towards the Frankfurt School, Ernst Bloch, and Herbert Marcuse, and their numerous adepts and followers in philosophy, sociology, political science, economics, psychology, etc. ${ }^{2}$ The scholarly discipline of modern history, by contrast, was characterized at the time by an opposition between the dominant mainstream political history in the vein of the historicist tradition, on the one hand, and structuralist social history representing the "progressive" Zeitgeist of the decade, on the other. ${ }^{3}$

It is, therefore, no wonder that during the first decade of its publication The Making remained largely unnoticed by mainstream German historians, not to speak of a broader readership. It was only with the growing interest

I. Robert M. Berdahl et al., Klassen und Kultur. Sozialantbropologische Perspektiven in der Geschichtsschreibung (Frankfurt am Main, 1982).

2. Adelheid von Saldern, "Markt für Marx. Literaturbetrieb und Lesebewegungen in der Bundesrepublik in den Sechziger- und Siebzigerjahren”, Archiv für Sozialgeschichte, 44 (2004), pp. I $49-180$.

3. For an overview of the development of the Bielefeld School, see Bettina Hitzer and Thomas Welskopp, “Die 'Bielefelder Schule' der westdeutschen Sozialgeschichte. Karriere eines geplanten Paradigmas?” in idem (eds), Die Bielefelder Sozialgeschichte (Bielefeld, 2010), pp. I 3-3 I. 
in the history of the working class in West Germany after I968 that its seminal impact on Anglophone scholarship attracted the curiosity of a few methodologically more interested social scientists and historians. This first phase of "domesticating" The Making among a group of younger adherers to West German "social science history" (Historische Sozialwissenschaft) will be used here to discuss the intimate relationship between the programmatic message of The Making and the politico-cultural environment within which it was written and received. For this purpose, I will focus on The Making's reception in the West German Zunft, i.e. the venerable "guild" of university-based professional historians. This implies a number of caveats with regard to what I am not going to do in the following pages. If one were to aim to cover the entire German-speaking world, one would have to include, firstly, all West German "outsiders", such as the group around Karl Heinz Roth inspired by the Italian operaismo approach, ${ }^{4}$ whose historiographical merit consisted in establishing in the I 970 s the notion of "another" working-class movement, i.e. beyond the constraints of Social Democratic and communist organizations, among German working-class historians,' and for whom Thompson was something like a model for a militant intellectual uniting "history" and "politics". 6 Interestingly, this "political" Thompson was affirmed again very recently by proponents of a post-communist left, venerating him as a quintessential "socialist humanist", standing in a tradition of twentiethcentury undogmatic and heretic Marxist intellectuals. ${ }^{7}$ For a complete picture, the GDR and the other German-speaking countries would have to be included too. In the GDR, the reception went in specific directions, although it remained very restricted: Jürgen Kuczynski's appraisal from I965 remained the only visible reaction until the publication of a German translation in West Germany in 1987. Even Hartmut Zwahr, undoubtedly the most innovative specialist in working-class history in the GDR, who had personally encountered Thompson at an international conference, did not (dare to?) mention The Making

4. For one of the starting points of this political and intellectual current, see Sergio Bologna, Paolo Carpignano, and Antonio Negri, Crisi e organizzazione operaia (Milan, 1974).

5. Karl Heinz Roth, Die "andere" Arbeiterbewegung und die Entwicklung der kapitalistischen Repression von I 880 bis zur Gegenwart. Ein Beitrag zum Neuverständnis der Klassengeschichte in Deutschland (Munich, 1974); Erhard Lucas, James Wickham, and Karl Heinz Roth, Arbeiterradikalismus und die "andere" Arbeiterbewegung. Zur Diskussion der Massenarbeiterthese (Bochum, 1977).

6. See Roth's committed and extremely detailed obituary of Thompson, which was undoubtedly the finest to appear in German on the occasion of Thompson's death in 1993: Karl Heinz Roth, "Edward P. Thompson (1924-1993): Historiker, Politiker und Theoretiker der Neuen Linken", 1999. Zeitschrift für Sozialgeschichte des 20. und 21. Jabrhunderts, 9:2 (1994), pp. I63-171.

7. See Christoph Jünke, "Die Tränen des Edward P. Thompson”, in idem, Streifzüge durch das rote 20. Jahrhundert (Hamburg, 20I4), pp. I I I-I 86. 
in his writings. ${ }^{8}$ Meanwhile, the reception in Switzerland and Austria was informed by constellations similar to those in West Germany. ${ }^{9}$

To understand the impact of The Making in West Germany properly, a broader view of the general reception of Thompson's full historiographical oeuvre by the end of the I970s is necessary. Detlev Puls in 1979 and Dieter Groh in I980 edited two widely read collections of essays that were crucial for popularizing the "Thompsonian" view of social history in West Germany. Puls's Wabrnebmungsformen und Protestverbalten [Forms of Perception and Protest Behaviour] collated Thompson's seminal "Moral Economy" essay and contributions by German and international historians inspired by Thompson. ${ }^{\text {I० }}$ Shortly after, Groh presented a selection of Thompson's finest articles under the title Plebejische Kultur und moralische Ökonomie [Plebeian Culture and Moral Economy] preceded by a long introduction, to which I will return later. ${ }^{\text {II }}$ Although none of these German mediators of Thompson failed to underline the outstanding relevance of The Making for Thompson's status as one of the leading British historians of the time, their main interest tended to lie in the issues and problematics typical for the "Moral Economy" essay. To some extent, this can be explained by a growing interest among German scholars in forms of popular protest and politics outside the traditions of organized labour. The very notion of "protest" denoted this shift of focus and turned into a term much en vogue among historians - although the term did not figure prominently in Thompson's own writings, as Karl Heinz Roth has pointed out. ${ }^{\mathrm{I2}}$

While the prevalence of "protest" was certainly also part of a common international 1968 zeitgeist marked by protest movements of all kinds around the world, the origins of organized working-class movements in England and Germany, in contrast, seemed to be very specific in each of these countries. The one had grown out of a century-long battle for popular

8. See his seminal study, Hartmut Zwahr, Zur Konstituierung des Proletariats als Klasse. Strukturuntersuchung über das Leipziger Proletariat wäbrend der industriellen Revolution (Munich, I98I).

9. On the reception (or lack thereof) of Thompson's work during the I960s and I970s in other German-speaking countries (GDR, Austria, and Switzerland), see Hans Medick, "E.P. Thompson und sein 'empirisches Idiom'. Bemerkungen zu Werk und Wirkung eines außergewöhnlichen Historikers", in Josef Ehmer, Tamara K. Hareven, and Richard Wall (eds), Historische Familienforschung. Ergebnisse und Kontroversen. Michael Mitterauer zum 60. Geburtstag. Unter Mitarbeit von Michael Mitteraner (Frankfurt am Main, 1997), pp. 69-83, 76.

Iо. Detlev Puls (ed.), Wabrnehmungsformen und Protestverbalten. Studien zur Lage der Unterschichten im I8. und I9. Jahrbundert (Frankfurt am Main, I979).

I I. Edward P. Thompson, Plebejische Kultur und moralische Ökonomie: Aufsätze zur englischen Sozialgeschichte des I 8. und I9. Jahrbunderts, selected and introduced by Dieter Groh (Frankfurt am Main, I980).

I2. Roth, "Edward P. Thompson", p. I70. 
rights while industrialization and marketization was underway; the other came late, after the breakthrough of industrialization, and was dominated by "Marxism" from early on. When, in the late i960s, the "classics" of Marx and Engels were rediscovered by German left-wing intellectuals, often in a reverential if not outright orthodox way, this historical background contributed to a blurred vision of the historical processes of class formation - a blurred vision that also hampered an understanding of The Making. At the beginning, only the sociologist Michael Vester, whose book on the Chartists and their precursors will be dealt with below, and the late Günther Lottes wrote historiographical monographs strongly inspired by The Making. While Vester reframed the ideas of Thompson in a rather problematic way, Lottes, a specialist in the history of the Enlightenment, picked up on the "Liberty Tree" theme in the first half of The Making and presented a widely researched analysis of the "theory and practice of English radicalism" in the eighteenth century. His was undoubtedly the most thorough appropriation of The Making in Germany for years to come. ${ }^{\mathrm{I}}$ By contrast, the themes of the second half of The Making, i.e. Thompson's epic narrative of "class constitution", of the interplay of economic determination and experience, political oppression, and the forging of a class culture were not a focus of this modest "first wave" of Thompson's reception in Germany. The same is true for his other "grand" monographs (on William Morris and Edward Blake) and, of course, his political writings, the latter reaching a totally different audience during the heyday of the international movement for nuclear disarmament around 1980 .

With regard to the theme of this article, the West German reception of The Making, my central argument will be that through the respective involvements of their societies with Nazism and World War II, Great Britain and West Germany constituted fundamentally different historical environments for engaging with Thompson's new approach to workingclass history. These two societies, though allies during the Cold War from the late I940s onwards, represented opposite poles of political cultures among Western societies of their time: triumphant and popular anti-fascism on the one hand; all-out military, political, and moral defeat of the extreme variant of fascism as a popular project on the other.

In a first step, I will thus reconstruct the contrastive conditions and obstacles for a creative reception of The Making at the time of its publication. In a second step, I will describe how this mixed reception of The Making gave way to its belated acknowledgement and appreciation as a

I 3. Günther Lottes, Politische Aufklärung und plebejisches Publikum. Zur Theorie und Praxis des englischen Radikalismus im späten I8. Jahrbundert (Munich, I979). Lottes also contributed the translations of Thompson's essays in the Groh and Puls volumes. 
"classic" of modern historiography during the years when West German social history scholarship was challenged both by Alltagsgeschichte (history of everyday life), women's and feminist history, and a growing critique of modernity, resulting in its translation into German (1987) and - during the following decades - its canonization in the field of cultural studies and humanities.

As a sort of epilogue, I propose to reflect on The Making's current timeliness in the post-Cold War and post-communist era. In the eastern part of the continent this was, and partly still is, an era of the rapid and, outside the EU, predatory construction or reconstruction of capitalism, including the swift and brutal "unmaking" and "making" of new working classes. It has, meanwhile, also become an era of popular struggles for freedom and social rights - scenarios that should reconfirm the rank of Thompson's epic as an evergreen of politically engaged historiography.

\section{"SUBJECTIVE REDUCTIONISM" ?}

In essence, the reception of The Making in West German historical scholarship in the late I970s and early I980s can be summed up as follows: readers were impressed by the empirically rich and exceptionally wellwritten 800-page book that went to the heart of the political, social, and cultural history of England in the eighteenth and nineteenth centuries. In particular, the author's empathy with individual actors, which he did not merely profess but demonstrate in numerous concrete accounts, conveyed an understanding of what was "new" and "different" about "social history from below". First and foremost, Thompson's book was a counterpoint to the widespread practice among social historians of posthumously squeezing their "heroes" into theoretically deduced categories and concepts of development, or to define them as politically "immature" or "mature" in relation to structures of production and ownership and hence force them into the Procrustean bed of a historical-philosophical master plan. This anti-reductionism and anti-economism, which The Making demonstrated in various individual examples, addressed a set of problems that German social historians of the late I970s were certainly familiar with.

This generally positive assessment was, however, often followed by an objection: there was no "theory". For many years, "lack of theory" remained the major criticism, especially when it came to drawing conclusions from a book like The Making for one's own historiographical practice. Some considerations by Dieter Groh, one of the most productive social historians researching the history of the German labour movement at the time, serve to illustrate this point. As mentioned, in 1980 he published a volume entitled Plebejische Kultur und moralische Ökonomie, which included German translations of several articles by Thompson and a 
comprehensive introduction by Groh himself. In the introduction, he summed up the strengths of Thompson's approach:

Thompson's contribution, among other things, is that he demonstrated in his empirical studies how to avoid the dilemma of economic reductionism: by decoding behaviour against the backdrop of cultural reference systems that follow a specific logic. This sort of reconstruction can contribute to our understanding of seemingly incomprehensible, "spontaneous", and disorganized phenomena such as "food riots" or "setting the price" actions. This way, we can analyse these events in a way that not only elucidates the experiences and expressions of the actors, but also reveals their underlying meaning. ${ }^{.4}$

Perhaps it is in the nature of the matter that any attempt to summarize the conceptual implications of a historiographical text is necessarily more "theoretical" than the text itself. Certainly Thompson would not have described his work in these words. He was known (and in some cases feared) for his unpretentious, but at times highly polemical theoretical argumentation. But Groh's paraphrasing was, in my view, nevertheless an accurate attempt to explain the specific potential of Thompson's approach to German readers, who were in most cases shaped (or deformed) by the then current, highly "structuralist" rendition of Marxist or Weberian ideas. In that sense, Groh's assessment might still be relevant. He then goes on to formulate the main points of criticism:

This achievement comes at the price of a mirror-inverted reductionism, which can be called subjectivist. "History from below" is reduced by the empathetic and patiently "listening" historian to the reconstruction of perception modes and the behaviour of individuals within their horizons of experience. This way, it is reduced to the intentions of the protagonists. Structural constraints of action as well as motivations and motives that - for whatever reason - are displaced or desymbolized are lost to this view. ${ }^{\text {Is }}$

However, Groh does not leave the criticism of subjectivist reductionism to the discretion of his readers; instead, he introduces a "safe" formula with which the unknown treasure of Thompson's historiography can be lifted after all: Pierre Bourdieu's theory of "social practice", ${ }^{16}$ embedded in David Lockwood's analytical differentiation between systemic and social integration. ${ }^{17}$ According to Groh, this combination of theories is particularly well suited to analyse the dialectic of economy and moral values without stepping into the trap of intentionalist reductionism. ${ }^{18}$

I4. Dieter Groh, "Zur Einführung” [Introduction], in Thompson, Plebejische Kultur, pp. 5-28, 23 f. All translations from the German are mine.

I5. Ibid., p. 24.

I6. See the main reference point of the time: Pierre Bourdieu, Outline of a Theory of Practice (Cambridge, 1977).

17. David Lockwood, "Social Integration and System Integration", in George K. Zollschan and Walter Hirsch (eds), Explorations in Social Change (London, 1964), pp. 244-257.

I8. Groh, “Zur Einführung”, p. 26. 
I will refrain from presenting evidence to the contrary and showing that Groh does not do justice to Thompson at this point. Suffice to say, Thompson does analyse "objective" facts and lets them "speak". He does not pursue history only from within. In the British discussion, various "Thompsonians" have defended The Making against similar objections (though not always benefiting its cause). ${ }^{19}$ The question must also remain unanswered whether any such attempt at transmitting or translating the products of other scientific cultures necessitates this sort of theorizing mediation. While the ideal would be to reconstruct, as far as possible, an author's ideas based upon his own premises, this sort of joy in theoretical combination can, in retrospect, turn out to be quite stimulating. In this case, for instance, Dieter Groh was one of the first prominent West German social historians to recognize the tremendous potential of Pierre Bourdieu as yet another West European post-Marxist "giant" - long before the "cultural-historical" "Bourdieu-for-historians" medleys that would become en vogue two decades later under the banner of a supposedly "new" cultural history. ${ }^{20}$

Groh, it should be noted, was not the only German social historian to interpret Thompson in this manner. Thompson's account was often praised as empirically and conceptually fascinating, but theoretically deficient. In order to make it suitable for German demands, something had to be added: a meta-concept, i.e. a "grand theory" of society, economy, and culture in the era of industrialization and modernization. And The Making was in some cases "augmented" in this way. A very early attempt, in 1970, to embark on such an endeavour was made not by a historian, but a sociologist, Michael Vester. He sort of retold The Making, turning it into an account of "The Development of the Proletariat as a Learning Process", a Bildungsroman with various "learning cycles" borrowed from economic history. ${ }^{2 \mathrm{I}}$ However, this work did not have any repercussions in social history.

Ten years later, around $\mathrm{i} 980$, The Making finally became well known also among German social historians - albeit indirectly, through its great resonance and broad reception among British and American social historians.

19. For further details, see Thomas Lindenberger, "Das 'empirische Idiom'. Geschichtsschreibung, Theorie und Politik in 'The Making of the English Working Class', ProKla, 70 (1988), pp. $167-188,174-176$.

20. See, for instance, Ingrid Gilcher-Holtey, "Kulturelle und symbolische Praktiken: das Unternehmen Pierre Bourdieu", in Wolfgang Hardtwig and Hans-Ulrich Wehler (eds), Kulturgeschichte heute (Göttingen, I996), pp. I I I-I 30; Sven Reichardt, "Bourdieu für Historiker? Ein kultursoziologisches Angebot an die Sozialgeschichte", in Thomas Mergel and Thomas Welskopp (eds), Geschichte zwischen Gesellschaft und Kultur: Beiträge zur Theoriedebatte (Munich, 1997), pp. 7I-94.

2. Michael Vester, Die Entstehung des Proletariats als Lernprozeß: Die Entstehung antikapitalistischer Theorie und Praxis in England I792-I848, with an introduction by Alfred Krovonza and Thomas Leithäuser (Frankfurt am Main, 1970). 
Moreover, this acknowledgement was rather reluctant at the beginning. Jürgen Kocka, for example, referred to The Making merely en passant, parenthetically, which reveals his wish to distance himself from Thompson. At first, Thompson was even apodictically excluded from the circle of serious reference literature: in his introduction to the special issue on Arbeiterkultur of the journal Geschichte und Gesellschaft in 1979, Kocka argues: "It [The Making] does not contain a clear classification of cultural phenomena or a neat definition of the working class, which leaves the social substance of this working-class culture more or less in the dark. These difficulties have to do with Thompson's extremely subjectivist definition of class (preface), which, to put it bluntly, defines the working class as working-class culture." 22 This brief reference to the "preface" relates to the much-cited introduction to The Making, in which Thompson develops his concept of a processual and relational definition of class in contrast to Ralf Dahrendorf's structural-functionalist understanding. ${ }^{2}{ }^{3}$ Three years later, this sort of brusque brushing aside of Thompson's work no longer seemed appropriate. In the meantime, more and more people had read not only the famous preface, with its famous "passages", but also the rich "rest" of the book. Now the assessments were more generous: "Ultimately, [Thompson] pays the price of neglecting the systemic character of the society he is studying for his analysis of the dimensions "experience" and "agency". As an influential forefather of the history of experience and culture, he anticipated not only many of its strengths, but also some of its weaknesses." 24

While the formula "many strengths, some weaknesses" represents a sensible shift in appreciation, Kocka does not further specify the weaknesses mentioned. In 1983 , he published his comprehensive social history of the emergence of the working class in Germany. Hidden in a lengthy footnote on various East and West German dogmatic Marxist definitions of class, one stumbles upon a positive reference to Thompson: "One of Thompson's great achievements is that he recognized, abandoned, and criticized this value-based assessment [of the historical emergence of social classes by historians] between the two poles 'avant-garde of the proletariat' and 'false consciousness'. However, he did not entirely abandon class analysis informed by Marxism." Citing the main points of criticism from I 982 outlined above, he still maintains, "Thompson's definition of class has

22. Jürgen Kocka, “Arbeiterkultur als Forschungsthema. Einleitende Bemerkungen”, Geschichte und Gesellschaft, 5:I (1979), pp. 5-I I, 9.

23. Thompson and Dahrendorf were related to each other not only in conceptual (though opposing) terms. On how the differences between Germany and Britain played out in the "transferability" of their work between the two countries, see the section "Social History and Post-Fascism" below.

24. Jürgen Kocka, "Klassen oder Kultur? Durchbrüche und Sackgassen in der Arbeitergeschichte", Merkur, 36:10 (1982), pp. 955-965. 
other weaknesses that make it inadvisable to adopt it." ${ }^{25}$ Interestingly, in the main text Kocka goes on to outline the agenda of historically reconstructing "wage labour and the emergence of class" by raising and combining various topoi and problems that The Making introduced into the historiography of the working class in the first place. ${ }^{26}$

There were many contradictions and inconsistencies in the West German debate, which was initially strongly shaped by structural history. This explains, to some degree, the reactions of German scholars to the new theories and issues Thompson introduced into the international writing of social history. On the whole, however, this largely failed reception of Thompson can be regarded as a minor episode in German social history. In any case, German historiography has succeeded in resolving and overcoming many of these constraints through its "own" means, i.e. by opening up to new critical approaches advocated by a younger generation of historians. Before moving on to some of the innovations in West German historiography during the 1980 s, it is worthwhile scrutinizing the causes of the late, and when it happened initially missed, encounter with E.P. Thompson and The Making in particular. The protracted acceptance of The Making appears symptomatic of the self-understanding of West German social history in the I970s and I980s, particularly of its self-image as a reform-oriented "progressive" enterprise, which can be read as a small, but emblematic aspect of the European history of humanities after the end of World War II.

\section{SOCIAL HISTORY AND POST-FASCISM}

Why this stubborn unwillingness to acknowledge the enormous potential of The Making among leading German social historians of the I960s and I970s? Trying to understand this oddity brings us back to the politics behind The Making and forces us to compare them with the politics behind the German social history evolving during I960s and I970s.

When Thompson set out to write history, Britain was a postwar society with a popular anti-fascist experience, which had won a triumphant victory and new options for a new future. In an introduction written to a recently published collection of early essays by Thompson, Cal Winslow points to

25. Idem, Lohnarbeit und Klassenbildung: Arbeiter und Arbeiterbewegung in Deutschland I800-I875 (Berlin [etc.], I983), p. 20.

26. In his most recent volume Arbeiterleben und Arbeiterkultur. Die Entstehung einer sozialen Klasse (Bonn, 201 5), pp. 22f., Kocka praises The Making's merits in overcoming the dominance of structural history in both the Marxian and the Weberian traditions of working-class history through its emphasis on class experience and the importance of inherited popular traditions for the process of class formation. Its assumed neglect of "solid structures" and "overarching processes" framing these experiences now clearly figures as subordinate. 
the widespread notion that the people and not Churchill had won the war against fascism on the one hand, and the high hopes of social reform and democracy after the victory of the Labour Party at the national elections in summer 1945 on the other. ${ }^{27}$ It is from this political culture and it dynamics during the Cold War that The Making emanated. Thompson's peers consisted of young intellectuals engaged in this popular culture as radicals, as anti-capitalists, and initially as communists, in any sense as Marxists. ${ }^{28}$

You could barely conceive of a bigger gap between political cultures than by comparing this to young intellectuals growing up in defeated post-fascist Germany during the same decade. If we recall the intellectual and social situation of the Federal Republic of Germany in the late i960s and early I970s, focusing in particular on the subject history, it becomes apparent why The Making did not have the same impact in Germany as it did in Britain - in contrast to the reception afforded the work in the academic communities of other countries (US, Italy). There are various factors that account for this difference. It is not just the simple fact that the combination of comprehensibility for a broad audience and a compassionate writing style in the analysis of highly complex historical issues has, at least since the Second World War, never been regarded as an important aim within German academic tradition. By contrast, British historiography represented a peculiarly literary tradition, linked with the broader political domain, and within it dissident leftist intellectuals could speak about national history to a broad audience, thereby also indirectly addressing urgent issues of the present. This was also constitutive for a work like The Making.

German political culture was crucially different at the time, also in other regards. There were good reasons why the newly emerging sub-discipline within West German historiography that liked to refer to itself as "social science history" (Historische Sozialwissenschaft) ${ }^{29}$ could not and would not understand the "empirical idiom of the British" that allowed Thompson to

27. See Cal Winslow, "Introduction", in idem (ed.), E.P. Thompson and the Making of the New Left: Essays and Polemics (New York, 2014), pp. I-36, I6. See also Ken Loach's documentary The Spirit of ' 45 (UK, 2013), which captures this moment of collective optimism and relief in a very moving and passionate way: www.thespiritof $45 . c 0 m$, last accessed I I January 20I6; and Geoff Eley, "Corporatism and the Social Democratic Moment: The Postwar Settlement, 1945-1973”, in Dan Stone (ed.), The Oxford Handbook of Postwar European History (Oxford, 20I 2), pp. 37-59, 4If.

28. For the implications of this political practice of education and theoretical debate see especially the following contribution to a Special Issue to mark the fiftieth anniversary of The Making: Madeleine Davis, "Edward Thompson's Ethics and Activism 1956-1963: Reflections on the Political Formation of The Making of the English Working Class", in idem and Kevin Morgan (eds), “'Causes That Were Lost'? Fifty Years of E.P. Thompson's The Making of the English Working Class as Contemporary History", Contemporary British History, 28:4 (2014), Special Issue, pp. $438-456$.

29. For a foundational text of this paradigm, see Hans-Ulrich Wehler, Geschichte als Historische Sozialwissenschaft (Frankfurt am Main, 1973). 
unfold a theoretically rich, historical argument. ${ }^{30}$ In the tradition of the "German theoretical idiom", this social history itself had only just stepped into the arena to challenge the hegemony of conventional political history. Re-examining and renegotiating theoretical presumptions and the political self-understanding of previous historiography in an explicit way became one of its hallmarks. With some consequentiality its proponents therefore lacked the sensibility to discern the theoretical potential in a fact-oriented narrative like The Making. The crude facts, graphic details, and countless episodes at the surface of its text could not echo their intellectual concerns and political attitudes.

This was not just a matter of dissimilarity in academic traditions. The horizon of collective political experience that shaped the social history "agendas" in the two countries is even more important in explaining the differences. In West Germany, approaching the subject of class formation and its impact on democratic politics took place in a postwar society with a popular fascist experience, which had brought about the complete material and, above all, moral and political disaster of the nation in its integrity, affecting all classes, all confessions, all ideological orientations.

What did this mean for the new young generation of historians in West Germany maturing during the I950s and I960s? What does this mean for the ways in which politics, in particular popular and democratic politics, interact with historical writing? It meant that while looking at the same subject, the working class and its historical formation as a social and political actor, the focus of attention was a totally different one. Fascism had come about not least as a consequence of a catastrophic defeat of workingclass politics. This had been a defeat not just at the ballot box; it had been a defeat that had gone hand in hand with the disintegration of working-class cultures during the late Weimar Republic and during the Nazi period. It had led not just to political apathy and individualization of workers, but also to massive collaboration and support of Nazi state politics, also by workers. Although working-class organizations had contributed more than other former parties to anti-Nazi resistance, the working class itself had ceased to exist as a political reality. It had lost its unique quality as a culture of resistance and of counter-hegemony that it had actually acquired during the long struggles for democratic citizenship and social equity since c.I 848 .

During these postwar decades, the task of German historians thus consisted of a critical historical investigation of the societal and political developments leading to 1933, and then to Auschwitz and 1945. This entailed not only reflecting on the undeniable and pervasive responsibility

30. See E.P. Thompson, "The Peculiarities of the English", The Socialist Register, 2 (1965), pp. 3II-362, and my analysis of its epistemological implications in Lindenberger, Empirisches Idiom, pp. 447-454. 
of the ruling classes, but also on the lack of popular support for anti-fascism and the widespread support for Nazi politics, including among the lower classes. Understanding the acquiescence of workers, why they had succumbed to nationalist ideology, why they had bought into Volksgemeinschaft and given up "class" as a focus of social identity - this was the intellectual challenge they were confronted with. In consequence, they were much more familiar with British historians such as Timothy Mason than with Thompson. ${ }^{3 \mathrm{I}}$

To conceive of a working class-history revolving around the idea of a "Liberty Tree" together with an emphatic reappraisal of this history as a tradition of popular politics carried little plausibility under these circumstances. This is one reason why The Making, though it was accepted as a valuable contribution to the history of industrialization and class formation, could barely resonate with the political concerns of German social historians at the time. In post-fascist West Germany, the highly political narrative of The Making, including its connotations of working-class education and of New Left radicalism, acquired a "sound" different from its original environment, which was characterized by a mix of victorious anti-fascism and the Cold War.

Considering the varying broader contexts, however, helps only to explain differences between Britain and West German scholarship at the level of the historical object of study as such. The picture can be rendered even more graphic by looking at the way in which the legacy of specific approaches within the discipline played into the understanding of this particular field of study. It was not that German academic history did not have any earlier experience with social history or people's history; this experience was also contrarious and rather paradoxical at that.

German historians of the first two postwar decades had been impregnated with a negative, or at least highly ambivalent, experience regarding history as a politically engaged practice. There had been attempts to develop something like a people's history (Volksgeschichte) within historical scholarship during the 1920 and I930s - but they were inspired rather by völkisch ideas, eventually teaming up with the Right and not the Left. During the Nazi dictatorship these historians (some of them methodologically quite innovative) had sided with the Nazis, and some of them had even contributed as experts to their genocidal politics during World War II..32 No wonder, then, that an approach reminiscent of Blut und Boden

3I. See, for instance, Mason's seminal study and collection of documents, Timothy W. Mason, Arbeiterklasse und Volksgemeinschaft. Dokumente und Materialien zur deutschen Arbeiterpolitik, 1936-1939 (Opladen, 1975).

32. The public controversy about the collusion between professional historiography and German right-wing politics was launched, among others, by historians Peter Schöttler and Götz Aly; see Peter Schöttler (ed.), Geschichtsschreibung als Legitimationswissenschaft 19I8-1945 (Frankfurt 
was not in high esteem after 1945, either among conservative proponents of conventional political history, or among the new generation of emphatic supporters of democratic values who had taken their chances to learn the lessons of re-education, thus coming to terms with the past (Vergangenheitsbewältigung) during the early years of the Federal Republic.

It was crucial for the professional formation of the generation of Hans-Ulrich Wehler, Jürgen Kocka, Hans and Wolfgang J. Mommsen, Dieter Groh, et al., however, that some of these former proponents of Volksgeschichte - in particular those, like Werner Conze and Theodor Schieder, still relatively young after I945 - were not only integrated or reintegrated into the university system, but became regretful, democratic liberals in Cold War West Germany. They instructed the young social historians who would later be so critical of The Making. ${ }^{33}$ Discussion about this component of the origins of West German social history did not start until the I990s. The results of an interview project conducted by Rüdiger Hohls and Konrad H. Jarausch, which were published in print in 2000, offer some insights into the intellectual atmosphere that cleared the ground for a critical and liberal, often also social-democratic social history in the Federal Republic. ${ }^{34}$ According to the memories of those from the younger generation interviewed, subjects like the elders' possible involvement in Nazi politics had remained a taboo in the conversations between mentors and disciples. Although the latter were themselves politicized during the I 960 s, in ways similar to their peers in other social sciences and humanities, a militant and engaged self-understanding of scholarship had no homestead in the colloquia with their mentors.

Thus, while Thompson and his generation of leftist non-conformists, many of them communists or former communists firmly connected to a democratic infrastructure of adult education, set out to stir up the Cold War stasis of politics and professional historiography, ${ }^{35}$ the political objectives of the leading West German social historians were entirely different. Admittedly, there existed also in West Germany a pre-1968 culture of intellectuals whose practical engagement in adult education resembled

am Main, 1997). It peaked in 1998 during a session of the biennial national convention of German historians (Historikertag) in Frankfurt am Main, documented in Winfried Schulze and Otto Gerhard Oexle (eds), Deutsche Historiker im Nationalsozialismus (Frankfurt am Main, 1999).

33. The exchange with Anglo-Saxon, in particular US-American, scholars, including several émigrés such as Hans Rosenberg, was another at least equally important component.

34. Rüdiger Hohls and Konrad H. Jarausch (eds), Versäumte Fragen: Deutsche Historiker im Schatten des Nationalsozialismus (Stuttgart [etc.], 2000).

35. For examples of such interventions, see E.P. Thompson, "Outside the Whale (1960)", in idem (ed.), The Poverty of Theory and Other Essays (London, I978), pp. I-33, originally published in idem (ed.), Out of Apathy (London, 1960), pp. I4I-194. 
Thompson's engagement in evening classes during the I950s: philosophers, sociologists, and jurists like Leo Kofler, Theo Pirker, Wolfgang Abendroth, to name the most prominent ones. ${ }^{36}$ But they were a relatively small group and not connected to the discipline of history in the "osmotic" way that was characteristic for Thompson's network. "Progressive” West German social historians at that time were thus in no position to recover and revive a legacy of "socialist humanism" deeply rooted in the political and intellectual culture of their country. Their prime concern, instead, was to finally break with the anti-liberal traditions within German intellectual and political culture, which had contributed not only to the establishment of the Nazi dictatorship but also to the "community of silence" that marked the early Federal Republic. An intellectual background of experience such as the one their British counterparts could draw on had historically been severed already in I933. The anti-fascist internationalism of the I930s and I940s had certainly not been the world of German middle-class intellectuals. Moreover, the mere fact that "anti-fascism" and "Marxism" alike had been promoted to central elements of communist state ideology within their own nation, but on the other side of the Iron Curtain, contributed to discrediting their intellectual and political ancestry as a legitimate source of inspiration.

The generational experience of National Socialism and the German Cold War thus provided a highly unpromising environment to receive, understand, and embrace the Anglo-Saxon variant of a compassionate social history firmly rooted in a pluralistic anti-fascist and left-wing tradition. It was much better suited for concepts of modernization or technocratic approaches, and for history in the idiom of structuralist social sciences. Thompson's historiographic practice was enabled by and rested on the politics of a fully legitimate left-wing populism, a legitimacy that, although contested and often marginalized, dated back several generations within the political culture of Great Britain. In post-fascist Germany, populism was inevitably associated with the extreme right (or with right- and left-wing totalitarianism in general), and politically engaged scholars, in particular historians, would keep it at bay: history should remain sober and rational; it should not again become contaminated with this disease. I think that this accounts a lot for the distanced and at least problematic relation to the working class as a historical subject in the double sense of the word.

36. See the impressive portrait of Kofler as an anti-Stalinist "socialist humanist" by Christoph Jünke, Sozialistisches Strandgut. Leo Kofler, Leben und Werk (1907-1995) (Hamburg, 2007). On the other proponents of a left-socialist opposition in early postwar West Germany, including Wolfgang Abendroth and Theo Pirker, see Gregor Kriditis, Linkssozialistische Opposition in der Ära Adenaner. Ein Beitrag zur Frühgeschichte der Bundesrepublik Deutschland Sozialistische Opposition zwischen Luftbrücke und Mauerbau (Hanover, 2008). 
This resulted, among other things, in a consistent asymmetry in terms of possible transfers between the academic cultures of Great Britain and post-fascist West Germany. Comparing two prominent and, in this context, highly emblematic figures may serve here as an illustration: Ralf Dahrendorf's sober and poignant observations about the Federal Republic as the successor society of the "Third Reich", which in many ways built on the latter's ambivalent modernization projects, but also his theory of class struggle in industrial society chimed nicely with the German postwar imperative to evaluate the modernization process since the nineteenth century in an analytical and matter-of-fact way, aiming at generalizations about class and society in late capitalism. He became a sort of progressive Wunderkind of the first generation, both of West German sociology and liberal politics. Meanwhile, Thompson's rather romantic attempt to historiographically do justice to the hopeless struggle of the Luddite machine destroyers has its origins in an entirely different tradition of reappraising and reclaiming the visionary legitimacy of past popular struggles within a highly idiosyncratic national context. Dahrendorf, being the son of a prominent social democratic resistance fighter persecuted by the Nazis, could easily travel back and forth between the two countries and its respective bourgeois worlds, ultimately reaching the peak of his career in Great Britain, where he taught as a professor at various universities and was created a baron. Edward P. Thompson, who in the preface to The Making attacked none other than Dahrendorf as a proponent of a structuralfunctionalist class theory, ${ }^{37}$ remained for a long time exotic and marginal among German social historians. Germany could easily "export” its most brilliant academic talent to Great Britain, while the authentic voices of popular culture fell on deaf ears in Germany.

\section{NEW POLITICS, HISTORIOGRAPHIC “TURNS”, AND THE CANONIZATION OF THE MAKING IN GERMANY}

However, The Making turned out to have a significant meaning for the subsequent generation of historians that emerged in the late I970s, the one introduced into social history by the Bielefeld School generation. I am now speaking, of course, of my own generation, which was too young to be marked by the politics of 1968 , but fully exposed to the impact of "new social movements" evolving during its aftermath in the I970s and I980s. This generation could seek and choose its options from within a broad leftliberal consensus established in consequence of 1968 in the academy and large parts of society alike. What this predicament could mean for younger "alternative" historians can be illustrated by recalling my personal 
"encounter" with The Making. I was then, during the late I970s, part of a student group majoring in history at the Free University (FU) in West Berlin, then still firmly enclosed by communist East Germany, but nevertheless a hotbed of left-wing activism, libertarian sub-cultures, and exciting intellectual experiments. As a self-organized "Studienkollektiv", we found ourselves pursuing a thorough education in Marxism in the philosophy department. Now, we wanted to find out what Marxist history as a scholarly pursuit might look like. Nothing of the sort was on offer in the very conservative history department at the FU, so we created our own syllabus alongside the official course programme and started reading German Marxist historiography, which at that time meant publications coming from close by, from the German Democratic Republic. There, after all, communists were in power and Marxism-Leninism was the only permissive frame for any historiography. While getting quickly frustrated over these readings, one day one of us put a large hardback volume (a copy from the university library) on the table and declared: "I found it! This is what we have to read." It was The Making of the English Working Class. We dropped East German Marxist historiography immediately and spent an entire year reading and trying to understand The Making. When the last page had been turned we came to the categorical conclusion: this has to be translated into German. ${ }^{38}$

Although we were beginners with regard to writing, not to speak of translating, Suhrkamp publishers, whose speciality, among others, had always been to bring into the German debate a range of advanced Marxist scholarship from all over the world, and who paid little attention to the opinion of established German historians, accepted our proposition immediately. Thus, we spent several years translating The Making while also writing our master's theses and engaging in some political activism here and there, including launching a history workshop movement in West Berlin and West Germany, inspired by the British example. ${ }^{39}$

What made this book so fascinating from the perspective of young historians involved in the new social movements of the post-I968 era? Firstly, we received The Making as a rare model of Marxist historiography breaking the monopoly of Marxism-Leninism in the field of historiography,

38. See Edward P. Thompson, Die Entstehung der englischen Arbeiterklasse, 2 vols, translated from the English by Lotte Eidenbenz, Mathias Eidenbenz,* Christoph Goffry, Thomas Lindenberger,* Gabriele Mischkowski, and Ray Mary Rosdale* (Frankfurt am Main, 1987). The names indicated with an asterisk had been members of the student group. Credit for making us read The Making goes to Manfred Gailus, who later specialized in, among other things, the history of moral economy and food riots. See Manfred Gailus, "Food Riots in Germany in the Late I 840 ", Past and Present, I45:I (1994), pp. I 57-193.

39. See Thomas Lindenberger and Michael Wildt, "Radical Plurality: History Workshops as a Practical Critique of Knowledge”, History Workshop, 33:I (1992), pp. 73-99. 
which, from a German perspective, had been established as a consequence of the Cold War intra-German polarization of intellectual and political life. It demonstrated the possibility of a radical critique of capitalism departing from the basic tenets of Marxian thinking, integrating "scientific" excellence and political commitment, and reaching out to a large audience - totally contrary to the tedious, dogmatic "short-course" type of party history typical of the GDR. It was the intriguing versatility of similar innovative historiographical movements of the time, which then, inspired by British Marxists as much as by the micro-history of Carlo Ginzburg and Giovanni Levi, by the Annales school and post-structuralism in France, and finally by US-American oral history and social anthropology, fused until the mid-I 980 in the programme of Alltagsgeschichte, the history of everyday life. ${ }^{4^{\circ}}$ Side by side and, to some extent, interacting with emerging feminist scholarship, this grew into a self-conscious and deliberate challenge to the established structurefunctionalist social history of the I960s and I970s, including its abstention from political militancy. According to an observer of the Frankfurter Allgemeine Zeitung, this yielded an astonishing fact: "History, which used in Germany to be such a solemn social science, is now the only discipline in the humanities that can boast a grass-roots movement". ${ }^{4 \mathrm{I}}$

Within the programme of Alltagsgeschichte the terms "agency" and "experience" played a key role, although they were not necessarily discussed with explicit reference to their frequent usage and discussion in Thompson's writing. The coinage and use of these concepts could also draw on some German intellectual sources, in particular the phenomenological sociology of the I920s, and thus amalgamated to form a characteristically German "idiom" of theoretically informed "history from below".

The subsequent story about The Making's German reception is quickly told. After a number of fierce debates and polemics culminating around 1984, Alltagsgeschichte became more or less integrated and accepted within the more refined understanding of social history. Joining the international trend, this "enhanced social history" ("Sozialgeschichte in der Erweiterung"), as it had already been postulated by Werner Conze as early as $1974,{ }^{42}$ was soon renamed and reinvented as "cultural history", representing from then on the mainstream approach to history in Germany until today, at least outside the field of the still rather "political" contemporary

40. See, for instance, the following English-language overview of this intellectual project: Alf Lüdtke (ed.), The History of Everyday Life: Reconstructing Historical Experiences and Ways of Life (Princeton, NJ, 1995).

4I. Gustav Seibt, "Grabe wo Du stehst. Die Kontroverse um die Alltagsgeschichte”, Frankfurter Allgemeine Zeitung, 22 September 1987, p. 36, quotation from Lindenberger and Wildt, "Radical Plurality", p. 74 .

42. See Werner Conze, "Sozialgeschichte in der Erweiterung", Nene Politische Literatur, I9 (1974), pp. 50I-508. 
history (Zeitgeschichte). Within this pluralist and "turn"-driven cultural history, The Making has meanwhile been widely accepted as an iconic model of "history from below". Consequently, the finest and most subtle works on the history of the German working class and their organizations, such as a brilliant study by Thomas Welskopp (who had been a student of Kocka) on the living world of the early social democrats, are postThompsonian in the best sense of the term. ${ }^{43}$ It has to be noted, too, that among many West German scholars the shift towards this "enhanced social history" had begun already before the German translation was finally published in 1987 under the title Die Entstehung der englischen Arbeiterklasse, as Günther Lottes duly noted in his excellent review article on this occasion. ${ }^{44}$ The Making's canonization since then can be traced by browsing thematic overviews and bibliographies. It figures as a classic when the issues of class constitution and the history of capitalism come up in textbooks and manuals. ${ }^{45}$ In a number of other humanities, it is referred to as a ground-breaking achievement in surveys on fields of study as diverse as the history and theory of pedagogy, ${ }^{46}$ communication and media studies, ${ }^{47}$ gender studies, ${ }^{48}$ social anthropology, ${ }^{49}$ not to mention "culture" in general. ${ }^{50}$ Consequently, The Making has become part of "normal science" also in Germany.

43. Thomas Welskopp, Das Banner der Brüderlichkeit. Die deutsche Sozialdemokratie vom Vormärz bis zum Sozialistengesetz (Bonn, 2000).

44. Günther Lottes, "Kopfgeburten der Sozialgeschichte - Ausgrabungen von unschätzbarem Wert. Über die Suggestivkraft von Edward P. Thompsons Klassiker 'The Making of the English Working Class' aus Anlass der deutschen Übersetzung”, Nene Politische Literatur, 32:3 (I987), pp. $477-489$.

45. See, for instance, Hans Joas and Wolfgang Knöbl, Sozialtheorie: Zwanzig einführende Vorlesungen (Frankfurt am Main, 2004), p. 403; Andreas Wirsching (ed.), Oldenbourg Geschichte Lebrbuch, vol. 4: Neneste Zeit (Munich, 2006), p. 202; Wolf Rainer Wendt, Geschichte der sozialen Arbeit, vol. I: Die Gesellschaft vor der sozialen Frage (Stuttgart, 2008), p. 193.

46. See Klaus Prange and Gabriele Strobel-Eisele, Die Formen des pädagogischen Handelns: Eine Einführung (Stuttgart, 2006), p. 206; Sigrid Blömeke, "Lehrerausbildung”, in Sabine Andresen et al. (eds), Handwörterbuch Erziehungswissenschaft (Weinheim [etc.], 2009), pp. 547-562, 552. 47. See Tanja Thomas and Friedrich Krotz, "Medienkultur und Soziales Handeln: Begriffsarbeiten zur Theorieentwicklung”, in Tanja Thomas (ed.), Medienkultur und soziales Handeln (Wiesbaden, 2008), pp. 17-42, 25.

48. Michael Vester and Daniel Gardemin, "Milieu und Klassenstruktur. Auflösung, Kontinuität oder Wandel der Klassengesellschaft?", in Claudia Rademacher and Peter Wiechens (eds), Geschlecht - Ethnizität - Klasse: Zur sozialen Konstruktion von Hierarchie und Differenz (Opladen, 200I), pp. 219-274, 255 .

49. Wolfgang Kaschuba, Einführung in die Europäische Ethnologie (Munich, 2006, 3rd ed.), pp. I04, I 20f.).

50. See Christoph Jacke, Medien(sub)kultur: Geschichten - Diskurse - Entwürfe (Bielefeld, 2004), p. ı68; Karl H. Hörning and Julia Reuter, Doing Culture: Neue Positionen zum Verbältnis von Kultur und sozialer Praxis (Bielefeld, 2004), p. I33; Peter Burke, "Einheit und Vielfalt der Kulturgeschichte [1997/1998]”, in Silvia Serena Tschopp (ed.), Kulturgeschichte (Stuttgart, 2008), pp. I $47-174$, I 49 . 


\section{B ACK TO SQUARE ONE? REVISITING THE MAKING IN A POST-COLD-WAR AND GLOBAL PERSPECTIVE}

(EPILOGUE)

This, then, was the state of the art in Germany established during the I990s, a politically turbulent decade for Europe and Germany, beginning with a series of successful democratic revolutions and ending with several transitions to liberal capitalism in Eastern Central Europe. The end of the Cold War stalemate also brought the reappearance of war and genocide within Europe, and the fall of an empire, the Soviet Union. What do these deep and sudden changes signify for the legacy of The Making as a history of class formation and of industrial capitalism, if taken both as scholarly practice and political engagement?

For historical scholarship the demise of communist regimes brought about a huge practical and intellectual challenge that also amounted to a unique opportunity: the making and unmaking not only of these dictatorships, but also the societies and cultures the communist dictators had suppressed and controlled during at least four, and in some larger areas up to seven, decades, could now be researched on the basis of abundant and newly accessible archival sources. This challenge had a tremendous effect on professional history in Germany. Interacting with the ongoing and even growing public interest in the past of the Nazi dictatorship and the Second World War, it contributed to a dynamic of expansion and public visibility of contemporary history, which now increasingly came to represent the discipline of history tout court in Germany. Can perspectives and approaches like the ones formulated in The Making still relate to these current questions and concerns?

It has to be acknowledged that the end of the Cold War has made some of the basic enquiries and findings of The Making more problematic than they might have been already - not least thanks to its being permeated by a very peculiar national culture. Thompson's statement that the idea of an alternative system has to take root if the process of class formation is to be completed is one of them. At the very end of The Making, he defines the new class consciousness achieved around I 830 in England as a consciousness, on the one hand, of identical interests among a diversity of people. Then he continues: "On the other hand, there was a consciousness of the identity of the interests of the working class, or 'productive classes' as against those of other classes; and within this there was maturing the claim for an alternative system." $5 \mathrm{I}$

Thompson emphasized "system" in order to denote an essential alternative to capitalism as a whole, i.e. to the total market system within 
which the working class as a social and cultural structure had come about, within whose politics it had established its "presence".

As is well known, workers and working-class consciousness were also massively "present" in some of the revolutions around 1989 . The latter were not only democratic, but also quickly turned out to be pro-market economy, in some instances with worker organizations assuming a leading role. They were informed more by Joan Robinson's famous aphorism, which, in its paraphrased form, says that "the only thing worse than being exploited by capitalism is not being exploited by capitalism" (which had become a sort of folk truism in the Eastern Bloc by the I980s) than by the ambitious projects to reform the socialist system, as propagated by Gorbachev, some enlightened apparatchiks, as well as by numerous dissident activists who quickly became a minority in the movements they had helped to bring about. With The Making at the back of our minds, we have to ask ourselves: How does this fit? How does The Making "sound" in the very region of world history where the first attempt to institutionalize such an "alternative system" to capitalism, namely state socialism, had turned out to be an all-out and catastrophic failure?

On the one hand, reflecting on this issue leads inevitably, again, to contextualizing The Making thoroughly in a peculiar historical setting, in its own time of being written, and to the fact that something like a "working class" and its potential to become a subject of democratic struggle is quintessentially contingent, and, seen in hindsight, even a rather unlikely "event". 52 This might be the sobering part of the story, at least regarding the future significance of the specific object of The Making.

On the other hand, we are faced, these days, with scenarios not so dissimilar from the epoch of early industrialization. The crumbling of Marxism-Leninism has left behind a vast vacuum that has been, starting more than two decades ago, reconquered by capitalist accumulation, partly in the most "primitive" (ursprünglich) way imaginable. This was and is capitalist transformation of the most violent kind, unfettered by regulation, predatory, and greedy, in particular if one looks at those parts of the former Soviet Empire that did not have the chance to quickly join the EU and its regime of regulated market economy and "social democracy". What is currently happening in Ukraine, Russia, Belarus, and other central Asian republics may well be comparable with the epoch of primitive accumulation and market revolution in Western Europe three centuries earlier, including the processes of class formation and of worker politics. Then, as now, the struggle for independent unions, for citizens' rights of

52. For an opposite view on the role of the working class (or, more precisely, the labour movement and the "left") as the most fundamental agent of democratization in Europe since the nineteenth century, see Geoff Eley, Forging Democracy: The History of the Left in Europe, I 850-2000 (Oxford [etc.], 2002). 
subsistence and political participation, were and are being fought with unbridled brutality, dividing whole nations by estranging the elites from the people, with gentry, oligarchs, and their lackeys on the one side, and peasants, workers, and townspeople on the other. ${ }^{53}$

What is true for the former Soviet Union applies also to other world regions, even in those "fortunate" areas in which capitalism, at least to some minimum extent, has been made comparably "safe" by state regulation and a functioning civil society. The brutal consequences of austerity politics in some of the crisis-stricken regions of the European Union and the successive waves of migration from the Global South to the Global North that we are witnessing today will certainly trigger the reconstitution of social classes and of class politics. Whether and how the social and political rights of the many and a capitalist future are reconcilable or not will be one of the fundamental stakes in the emergence of new political movements both on the far left and on the far right. Will a book like The Making remain useful reading when it comes to understanding these renewed dynamics of capitalist development and democratic struggles? I think so, but only by taking a stance of critical relativization, rather than of imitative appropriation. Reading The Making can still, I am quite sure, enhance the imagination and sharpen analytical sensibilities, but not by positing the historical "making of a working class", as it "happened" in Western Europe in several countries, as a sort of historical "gold standard" or a "holy grail", which has to be searched for in countries undergoing capitalist transformation or retransformation in our days.

The Making has to be read attentively, keeping in mind the structure of this epic. After clarifying his view on "class" and the history of its formation in the famous preface, Thompson forces the reader to cope with 200 pages filled with a long and highly idiosyncratic prehistory of popular politics before the first capitalists and workers even took to the stage. It is this ground-breaking shift of emphasis within working-class history that has to be embraced among Thompson's multiple and highly original insights. The ultimate telos of The Making, after all, is not the working class for the sake of the working class, but, in the terminology of today, human rights and democracy. At the very end of his account, when he looks back in a somewhat melancholic tone on the historical failure of a combination between the early English working-class movement and the anti-utilitarian critique of Romanticism, Thompson concludes: "Yet the working people should not be seen only as the lost myriads of eternity. They had also nourished, for fifty years, and with incomparable

53. For an impressive allegory of these new-old class struggles see the highly reflective, but thrilling feature film $\mathrm{Za}$ Marksa (For Marx) (Russia, 2013, dir. Svetlana Baskova), to be seen on youtube.com. 
fortitude, the Liberty Tree. We may thank them for these years of heroic culture." 54

\author{
TRANSLATED ABSTRACTS \\ FRENCH - GERMAN - SPANISH
}

Thomas Lindenberger. Du structuralisme au culturalisme: la longue réception de The Making et son actualité, réévaluée dans une perspective de l'après-Guerre froide.

En se fondant sur l'expérience de l'auteur, qui est l'un des traducteurs en allemand de The Making of the English Working Class (titre français: La Formation de la classe ouvrière anglaise) cette article décrit la longue réception contradictoire de l'ouvrage en Allemagne. Lorsque le magnum opus d'E.P. Thompson parut il y a cinquante ans, les érudits allemands des deux côtés du Rideau de fer manquèrent de le remarquer pendant plusieurs années. La réception relativement silencieuse en Allemagne de l'Ouest dans les années 1970 fut marquée par son rejet en tant qu'ouvrage manquant de théorie et étant «subjectiviste». En examinant les contextes contrastés du Royaume-Uni de l'Après-guerre, avec son expérience populaire anti-fasciste, et de l'Allemagne de l'Ouest post-fasciste, il est possible de comprendre les raisons pour lesquelles «l'idiome empirique» de Thompson de l'histoire des classes ne parvint pas à toucher une corde sensible à l'époque auprès des grands représentants de la nouvelle génération des historiens de l'histoire "progressive» en Allemagne et d'un plus vaste public de lecteurs. Ce n'est qu'avec l'arrivée de l'Alltagsgeschichte, l'histoire féministe, et plus largement le tournant culturel dans les humanités que The Making et sa traduction en allemand devinrent un point de référence canonique, tant dans l'histoire de la classe ouvrière que dans les humanités en général. Un bref épilogue présente son potentiel durable pour une compréhension historique des processus actuels de la formation des classes dans l'Après-guerre et des luttes pour les droits de l'homme.

Traduction: Christine Plard

Thomas Lindenberger. Vom Strukturalismus zum Kulturalismus: Die langwierige deutsche Rezeption von The Making und die Aktualität des Werks, neu bewertet aus der Perspektive der Zeit nach dem Kalten Krieg.

Ausgehend von den Erfahrungen des Autors als eines der deutschen Übersetzer von The Making of the English Working Class (deutscher Titel: Die Entstebung der englischen Arbeiterklasse) legt der Beitrag die langwierige und widerspruchsvolle Rezeption dieses Werks in Deutschland dar. Als E.P. Thompsons Hauptwerk vor fünzig Jahren veröffentlicht wurde, nahmen es deutsche Forscher auf beiden Seiten des Eisernen Vorgangs mehrere Jahre lang nicht zur Kenntnis. Die recht verhaltene Rezeption im Westdeutschland der I $970 e r$ Jahre war durch die Ablehnung des Werks 
als zu untheoretisch und „subjektivistisch” gekennzeichnet. Ein Blick auf die gegensätzlichen Kontexte Nachkriegs-Großbritanniens - mit seiner von der allgemeinen Bevölkerung getragenen Erfahrung des Antifaschismus - und des postfaschistischen Westdeutschland kann erklären helfen, weshalb Thompsons „empirisches Idiom“ der Klassengeschichte bei den führenden Vertretern einer neuen Generation „progressiver" deutscher Sozialhistoriker und einem breiteren Lesepublikum damals keinen Anklang fand. Erst mit der Entwicklung der Alltagsgeschichte, der feministischen Geschichtsschreibung sowie allgemeiner des cultural turn in den Geisteswissenschaften wurden The Making und seine deutsche Übersetzung zu kanonischen Bezugspunkten sowohl der Arbeiterklassengeschichte als auch der Geisteswissenschaften im Allgemeinen. In einem kurzen Epilog wird das bleibende Potenzial des Werkes für ein historisches Verständnis der heutigen, jenseits des Kalten Krieges verlaufenden Prozesse der Klassenformierung und der Kämpfe um Menschenrechte erörtert.

Übersetzung: Max Henninger

Thomas Lindenberger. Del estructuralismo al culturalismo: la dilatada recepción de The Making y su actualidad reconsiderada desde una perspectiva de la post-Guerra Fría.

Basándose en la experiencia del autor como uno de los traductores al alemán de The Making of the English Working Class (título español: La formación de la clase obrera en Inglaterra) en este texto se expone la dilatada y contradictoria recepción de esta obra en Alemania. Cuando la magnum opus de E.P. Thompson se publicó hace cincuenta años, al mundo académico alemán de ambos lados del Telón de acero se le pasó el tomar nota de ello durante varios años. La relativamente silenciada recepción en Alemania Occidental a lo largo de la década de 1970 se caracterizó por el rechazo arguyendo la carencia de un marco teórico y el "subjetivismo". El examen contrastado de los contextos de la Gran Bretaña de post-guerra, con su experiencia popular antifascista, y de la Alemania Occidental post-fascista, resulta útil para comprender por qué el "lenguaje empírico" de la historia de la clase obrera planteado por Thompson fracasó en su momento a la hora de llamar la atención tanto de los representantes más relevantes de la nueva generación de historiadores sociales "progresistas" en Alemania como de un público lector mucho más extenso. Fue tan sólo con la llegada de la Alltagsgeschichte, de la historia feminista y, de forma mucho más general, del giro cultural en las humanidades que The Making y su traducción al alemán llegaron a convertirse en un punto de referencia canónico tanto en la historia específica de la clase obrera como en el ámbito más amplio de las humanidades. Un breve epílogo analiza su perdurable potencial como herramienta de comprensión histórica de los procesos actuales de formación de clase en el mundo de la postGuerra Fría y en las luchas por los derechos humanos.

Traduccíon: Vicent Sanz Rozalén 